\title{
Computerized clinical decision support systems for chronic disease management: A decision- maker-researcher partnership systematic review
}

\author{
Pavel S Roshanov', Shikha Misra², Hertzel C Gerstein ${ }^{3,4}$, Amit X Garg ${ }^{5}$, Rolf J Sebaldt ${ }^{3}$, Jean A Mackay ${ }^{6}$, \\ Lorraine Weise-Kelly ${ }^{6}$, Tamara Navarro ${ }^{6}$, Nancy L Wilczynski ${ }^{6}$ and R Brian Haynes ${ }^{3,4,6^{*}}$, for \\ the CCDSS Systematic Review Team
}

\begin{abstract}
Background: The use of computerized clinical decision support systems (CCDSSs) may improve chronic disease management, which requires recurrent visits to multiple health professionals, ongoing disease and treatment monitoring, and patient behavior modification. The objective of this review was to determine if CCDSSs improve the processes of chronic care (such as diagnosis, treatment, and monitoring of disease) and associated patient outcomes (such as effects on biomarkers and clinical exacerbations).

Methods: We conducted a decision-maker-researcher partnership systematic review. We searched MEDLINE, EMBASE, Ovid's EBM Reviews database, Inspec, and reference lists for potentially eligible articles published up to January 2010. We included randomized controlled trials that compared the use of CCDSSs to usual practice or nonCCDSS controls. Trials were eligible if at least one component of the CCDSS was designed to support chronic disease management. We considered studies 'positive' if they showed a statistically significant improvement in at least $50 \%$ of relevant outcomes.

Results: Of 55 included trials, 87\% $(n=48)$ measured system impact on the process of care and 52\% $(n=25)$ of those demonstrated statistically significant improvements. Sixty-five percent (36/55) of trials measured impact on, typically, non-major (surrogate) patient outcomes, and 31\% $(n=11)$ of those demonstrated benefits. Factors of interest to decision makers, such as cost, user satisfaction, system interface and feature sets, unique design and deployment characteristics, and effects on user workflow were rarely investigated or reported.

Conclusions: A small majority (just over half) of CCDSSs improved care processes in chronic disease management and some improved patient health. Policy makers, healthcare administrators, and practitioners should be aware that the evidence of CCDSS effectiveness is limited, especially with respect to the small number and size of studies measuring patient outcomes.
\end{abstract}

\section{Background}

Chronic conditions present patients, practitioners, and healthcare systems with some unique demands, including recurrent visits, adherence to complex care plans, long-term disease and treatment monitoring, behavior modification, and patient self-management. For the many patients with multiple co-morbidities [1],

\footnotetext{
* Correspondence: bhaynes@mcmaster.ca

${ }^{3}$ Department of Medicine, McMaster University, 1280 Main Street West, Hamilton, ON, Canada

Full list of author information is available at the end of the article
}

overlapping or diverging care plans may further complicate these processes.

Computerized clinical decision support systems (CCDSSs) may help practitioners meet the requirements of chronic care. These systems analyze a patient's characteristics to provide tailored recommendations for diagnosis, treatment, patient education, adequate follow-up, and timely monitoring of disease indicators. For example, Holbrook et al. $[2,3]$ gave providers and diabetic patients access to a web-based system that offered care advice, allowed monitoring of diabetes risk factors, and




tracked key care targets. As with any health intervention, however, rigorous testing is warranted to determine whether CCDSSs improve chronic care processes and patient outcomes.

In our previous review of the effects of CCDSSs [4], we analyzed 100 randomized and non-randomized studies published until September 2004, 40 of which assessed the effects of CCDSSs on disease management. Of these 40 studies, 37 measured processes of care of which $62 \%$ (23) showed an improvement, and 27 measured patient outcomes of which 19\% (5) showed an improvement. The quality of the studies varied widely, but improved over time.

Many new randomized controlled trials (RCTs) have been published in this field since our previous work, potentially documenting important advances. Recognizing that the management of chronic disease has unique characteristics, we wished to review the impact of CCDSSs on the quality and effectiveness of chronic care. We had the opportunity to include the perspectives of senior hospital managers and front-line healthcare practitioners to ensure that relevant data were extracted and summarized-a level of stakeholder engagement that has not been included in other reviews [5-8].

\section{Methods}

We previously published the details of our review protocol, openly accessible at http://www.implementationscience.com/content/5/1/12[9]. These methods are briefly summarized here, along with details specific to this review of CCDSSs for chronic disease management.

\section{Research question}

Do CCDSSs improve chronic disease management processes or patient outcomes?

\section{Partnering with decision makers}

We conducted this review in partnership with individuals responsible for implementing CCDSSs in our region [9]. Decision makers, both managers and clinicians, met with the review team periodically to discuss direction and specific details for the data extraction, analysis, presentation and interpretation of results.

\section{Search strategy}

Full details of our search strategy are in our review protocol [9]. In summary, we searched MEDLINE, EMBASE, Ovid's Evidence-Based Medicine Reviews, and Inspec until 6 January 2010, and reviewed the reference lists of included RCTs and relevant systematic reviews. We screened articles for eligibility in two stages: a duplicate, independent review of titles and abstracts followed by a duplicate, independent, full-text review of potentially eligible articles, with a third reviewer resolving disagreements.

\section{Study selection}

We selected RCTs of a CCDSS used by a health care provider for management of chronic conditions, published up to 6 January 2010 in any language that measured CCDSS impact on processes of care or patient outcomes. We included RCTs in any language that compared patient care with a CCDSS to routine care without a CCDSS and evaluated clinical performance (i.e., a measure of process of care) or a patient outcome. Additionally, to be included in the review, the CCDSS had to provide patient-specific advice that was reviewed by a healthcare practitioner before any clinical action. Studies were excluded if the system was used solely by students, only provided summaries of patient information, provided feedback on groups of patients without individual assessment, only provided computer-aided instruction, or was used for image analysis. Trials included in our previous review [4] were included if they were eligible. Trials of CCDSSs for managing narrow therapeutic index medications used in some chronic conditions (such as warfarin in atrial fibrillation [10]) were not included in this review, but are discussed in our review for therapeutic drug monitoring and dosing.

\section{Data extraction}

To meet the needs of our management and clinical partners, we extracted study characteristics (e.g., study design, size, setting, authorship, funding, and year of publication) and system characteristics (e.g., integration with other systems, user interface elements, methods of data entry and delivery of recommendations, target users, and implementation details such as pilot testing and user training). Disagreements were resolved by a third reviewer or by consensus. We contacted primary authors to provide missing data and to assess the accuracy of the extracted data; 78\% (43/55) provided input. For the remaining trials, a trained reviewer assessed the extraction form against the full-text to confirm accuracy.

\section{Assessment of study quality}

Using a 10-point scale, pairs of reviewers independently evaluated the selected trials on five dimensions of quality, including concealment of allocation, appropriate unit of allocation, appropriate adjustment for baseline differences, appropriate blinding of assessment, and adequate follow-up [9]. We used a 2-tailed Mann-Whitney $\mathrm{U}$ test to compare methodologic scores between trials published before the year 2000 and those published later to determine if trial quality has improved with time.

\section{Assessment of CCDSS intervention effects}

We assessed the effectiveness of CCDSSs in each trial for improving process of care and patient outcomes. We defined process outcomes as changes in care activities 
such as diagnosis, treatment, and monitoring of disease. Examples of patient outcomes included changes in blood pressure, clinical events and health-related quality of life. We judged a CCDSS effective if it produced a statistically significant $(p<0.05)$ improvement in a primary chronic disease outcome or in $\geq 50 \%$ of multiple relevant pre-specified outcomes. We considered primary any outcome that trial reports described as 'primary' or 'main.' If authors did not designate a primary outcome, we considered the outcome used to calculate the trial's sample size to be primary, if reported. When there were no pre-specified outcomes, the system was considered effective if it produced an improvement in $\geq 50 \%$ of all reported chronic disease outcomes. Our assessment criteria are more specific than those used in our 2005 review [4]; therefore, the assignment of effect was adjusted for some trials included in the review.

\section{Data synthesis and analysis}

We summarized data using proportions, medians, and ranges. Denominators vary in some proportions because not all trials reported relevant information. All analyses were carried out using SPSS, version 15.0. We did not attempt a meta-analysis because of study-level differences in participants, clinical settings, disease conditions, interventions, and outcomes measured.

We conducted a sensitivity analysis to assess the possibility of biased results in studies with a mismatch between the unit of allocation (e.g., clinicians) and the unit of analysis (e.g., individual patients without adjustment for clustering). We compared success rates between studies with matched and mismatched analyses using chi-square for comparisons. No differences in reported success were found for either process of care outcomes (Pearson $\mathrm{X}^{2}=1.41, p=0.24$ ) or patient outcomes (Pearson $\mathrm{X}^{2}=1.45, p=0.23$ ). Accordingly, results have been reported without distinction for mismatch.

\section{Results}

Figure 1 shows a flow diagram of included and excluded trials. We identified 166 trials of CCDSSs and Cohen's $\kappa$ for reviewer agreement on trial eligibility was 0.93 (95\% confidence interval [CI], 0.91 to 0.94 ). In this review, we included 71 publications describing 55 trials (33\% of total) about management of chronic diseases [2,3,11-79]. Thirty-eight included studies contributed outcomes to both this review and other CCDSS interventions in the series; three studies $[30,53,62]$ to four reviews, 12 studies $[21,25,28,31-33,42-44,51,52,54,55,57-61,74]$ to three reviews, and 23 studies $[2,3,11,12,18,19,23,27$, $35-38,40,41,45,46,48-50,56,67,71-73,77,79]$ to two reviews; but we focused here on outcomes relevant to the management of chronic disease.

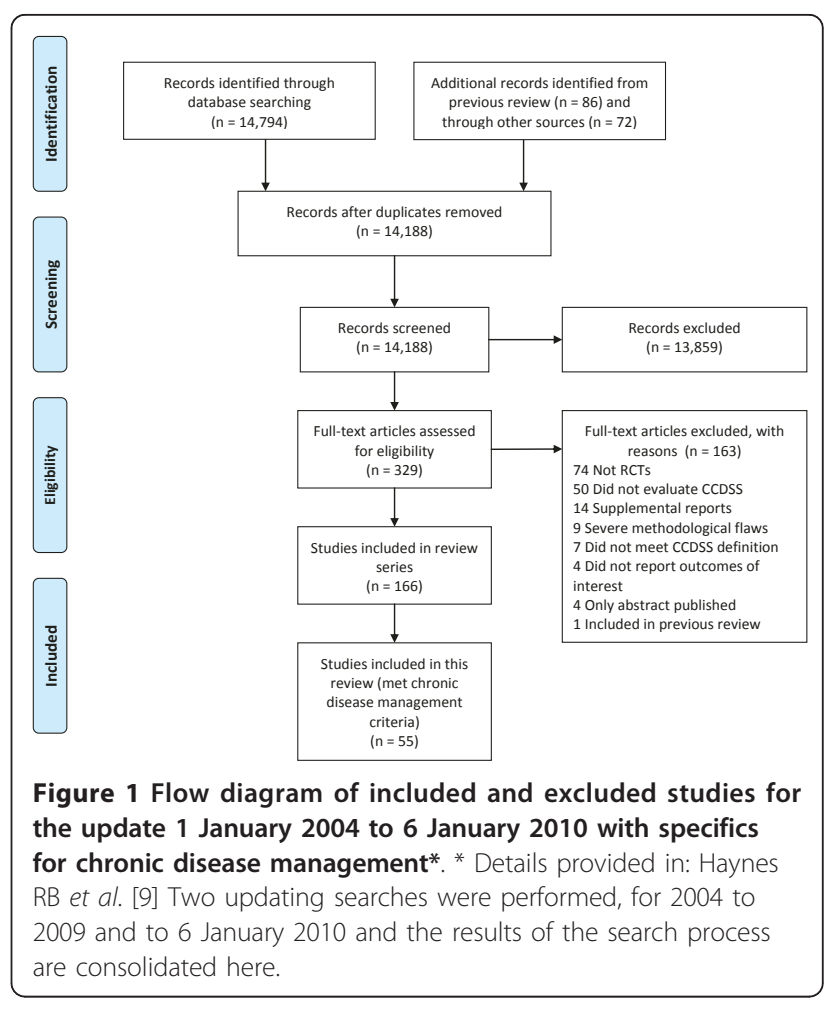

Summary of trial quality is reported in Additional file 1, Table S1; system characteristics in Additional file 2, Table S2; study characteristics in Additional file 3, Table S3; outcome data in Table 1 and Additional file 4, Table S4; and other CCDSS-related outcomes in Additional file 5, Table S5.

\section{Study quality}

Additional file 1, Table S1 presents details of our methodological quality assessment. Of the 55 trials, 53\% reported adequate concealment of allocation [2,3,13,18,20,27,29,31-34,37,39,40,47-58,60-67,72-75]; $78 \%$ showed no differences in baseline characteristics between study groups or adjusted accordingly $[2,3,11-13,18-21,23-25,28,29,34,36,38-58,60-67,70-72,74-$ $76,78,79] ; 53 \%$ allocated entire wards or practices to each study group $[11,12,14-18,25,28-35,37,39,46$ 49,51,54-59,62-64,67,70,73,76-79]; all except one used objective outcomes or blinding of outcome assessments [23]; and $60 \%$ achieved a $\geq 90 \%$ follow-up rate for their unit of analysis [11-13,18-24,27,30,35,36,39,40,46, 47,50-55,59-62,65-70,73,74,76,77]. The overall quality of trials was good (median methods score, 8; ranging from 2 to 10 ) and improved with time (median methods score before versus after year 2000, 7 versus 8, 2-tailed Mann-Whitney $U=137 ; p=0.005$ ), possibly because early trials often failed to conceal allocation or to achieve adequate follow-up. 
Table 1 Results for CCDSS trials of chronic disease management

\begin{tabular}{|c|c|c|c|c|c|c|c|}
\hline Study & $\begin{array}{l}\text { Methods } \\
\text { Score }\end{array}$ & Indication & $\begin{array}{l}\text { No. of } \\
\text { centres/ } \\
\text { providers/ } \\
\text { patients }\end{array}$ & Process of care outcomes & $\begin{array}{l}\text { CCDSS } \\
\text { Effect }^{\mathrm{a}}\end{array}$ & Patient outcomes & $\begin{array}{l}\text { CCDSS } \\
\text { Effect }^{\mathrm{a}}\end{array}$ \\
\hline \multicolumn{8}{|c|}{ Diabetes } \\
\hline $\begin{array}{l}\text { Holbrook, } 2009 \\
{[2,3]}\end{array}$ & 7 & $\begin{array}{l}\text { Web-based tracking of } \\
\text { diabetes monitoring in } \\
\text { adults in primary care. }\end{array}$ & $18 / 46 / 511^{*}$ & $\begin{array}{l}\text { Measurement of } \mathrm{HbA}_{1 c}, \mathrm{BP}, \\
\mathrm{LDL}-\mathrm{C} \text {, albuminuria, } \mathrm{BMI}, \\
\text { exercise, and smoking } \\
\text { status; foot surveillance. }\end{array}$ & + & $\begin{array}{l}\text { Levels of } \mathrm{BP}, \mathrm{LDL}-\mathrm{C}, \mathrm{HbA}_{1 \mathrm{c}} \\
\text { and albuminuria; } \mathrm{BMI} \text {, } \\
\text { exercise rate, absence of } \\
\text { foot neuropathy and } \\
\text { smoking; quality of life. }\end{array}$ & + \\
\hline $\begin{array}{l}\text { Maclean, } 2009 \\
{[11,12]}\end{array}$ & 8 & $\begin{array}{l}\text { Reminders for the } \\
\text { management of diabetes in } \\
\text { primary care. }\end{array}$ & $\begin{array}{l}64 * 132 / \\
7,412\end{array}$ & $\begin{array}{l}\text { Test completion within } \\
\text { guideline-specified times } \\
\text { (HbA } A_{1 c} \text { lipids, serum } \\
\text { creatinine, and urine } \\
\text { microalbumin). }\end{array}$ & + & $\begin{array}{l}\text { Mean } \mathrm{HbA}_{1 c} \text { level; patients } \\
\text { with } \mathrm{HbA}_{1 c}<7 \% \text {. }\end{array}$ & 0 \\
\hline $\begin{array}{l}\text { Christian, } 2008 \\
\text { [13] }\end{array}$ & 8 & $\begin{array}{l}\text { Patient feedback and } \\
\text { physician } \\
\text { recommendations for } \\
\text { management obesity and } \\
\text { type } 2 \text { diabetes in primary } \\
\text { care. }\end{array}$ & $2 / 19 / 273^{*}$ & $\ldots$ & $\ldots$ & $\begin{array}{l}\text { Weight change; patients } \\
\text { with } \geq 5 \% \text { weight loss. }\end{array}$ & + \\
\hline $\begin{array}{l}\text { Cleveringa2008 } \\
{[14-17]}\end{array}$ & 6 & $\begin{array}{l}\text { Recommendations for } \\
\text { management of type } 2 \\
\text { diabetes in primary care. }\end{array}$ & $\begin{array}{l}55^{*} / \\
\ldots / 3,391\end{array}$ & $\begin{array}{l}\text { Diabetes treatment } \\
\text { satisfaction score. }\end{array}$ & 0 & Mean $\mathrm{HbA}_{1 \mathrm{c}}$. & 0 \\
\hline $\begin{array}{l}\text { Peterson, } 2008 \\
\text { [18] }\end{array}$ & 10 & $\begin{array}{l}\text { Visit reminders and patient- } \\
\text { specific physician alerts and } \\
\text { progress reports for } \\
\text { organization of primary } \\
\text { care in patients with type } 2 \\
\text { diabetes. }\end{array}$ & $\begin{array}{l}24^{*} / 238 / \\
7,101\end{array}$ & $\begin{array}{l}\text { Completion of foot and } \\
\text { eye exams, } \mathrm{BP} \text { monitoring, } \\
\text { and renal, } \mathrm{HbA}_{1 c} \text {, and LDL- } \\
\mathrm{C} \text { tests. }\end{array}$ & + & $\begin{array}{l}\text { Patients with target } \\
\text { composite clinical outcome } \\
\left(\mathrm{SBP}<130 \mathrm{~mm} \mathrm{Hg}, \mathrm{HbA}_{1 \mathrm{c}}\right. \\
<7 \% \text {, and } \mathrm{LDL}-\mathrm{C}<100 \mathrm{mg} / \\
\mathrm{dL} \text { ). }\end{array}$ & + \\
\hline Quinn, 2008[19] & 6 & $\begin{array}{l}\text { Cell phone-based type } 2 \\
\text { diabetes management, } \\
\text { with real-time coaching for } \\
\text { patients and remote } \\
\text { monitoring of blood } \\
\text { glucose for practitioners in } \\
\text { primary care. }\end{array}$ & $3 / 26 / 30^{*}$ & $\begin{array}{l}\text { Medications intensified and } \\
\text { medication errors } \\
\text { identified. }\end{array}$ & + & Mean $\mathrm{HbA}_{1 \mathrm{c}}$. & + \\
\hline $\begin{array}{l}\text { Augstein, } 2007 \\
{[20]}\end{array}$ & 8 & $\begin{array}{l}\text { Recommendations for } \\
\text { management of diabetes in } \\
\text { outpatients. }\end{array}$ & $5 / 5 / 49^{*}$ & $\ldots$ & $\ldots$ & $\begin{array}{l}\text { Change in } \mathrm{HbA}_{1 c} \text { and } \\
\text { glucose levels. }\end{array}$ & + \\
\hline Filippi, 2003[21] & 7 & $\begin{array}{l}\text { Reminders for prescribing } \\
\text { of anti-platelet medications } \\
\text { to diabetic primary care } \\
\text { patients. }\end{array}$ & $\begin{array}{l}. . / 300 * / \\
15,343\end{array}$ & $\begin{array}{l}\text { Patients with antiplatelet } \\
\text { drug prescriptions. }\end{array}$ & + & $\ldots$ & $\ldots$ \\
\hline Meigs, 2003[22] & 6 & $\begin{array}{l}\text { Feedback for management } \\
\text { of type } 2 \text { diabetes in a } \\
\text { hospital-based internal } \\
\text { medicine clinic. }\end{array}$ & $1 / 66^{*} / 598$ & $\begin{array}{l}\text { Use of } \mathrm{HbA}_{1 c} \text { and } \mathrm{LDL}-\mathrm{C} \\
\text { tests; } \mathrm{BP} \text { measurement; eye } \\
\text { and foot exams. }\end{array}$ & 0 & $\begin{array}{l}\text { Patients with } \mathrm{HbA}_{1 c}<7 \% \text {; } \\
\text { change in } \mathrm{HbA}_{1 c} \text { levels. }\end{array}$ & 0 \\
\hline $\begin{array}{l}\text { Lobach, } 1997 \\
\text { [23] }\end{array}$ & 6 & $\begin{array}{l}\text { Recommendations for } \\
\text { screening, monitoring, and } \\
\text { management of diabetes in } \\
\text { primary care. }\end{array}$ & $1 / 58^{*} / 497$ & $\begin{array}{l}\text { Compliance with diabetes } \\
\text { management } \\
\text { recommendations (foot, } \\
\text { ophthalmologic, and } \\
\text { complete physical exams; } \\
\text { chronic glycaemia } \\
\text { monitoring; urine protein } \\
\text { and cholesterol levels; and } \\
\text { influenza and } \\
\text { pneumococcal } \\
\text { vaccinations). }\end{array}$ & + & $\ldots$ & $\ldots$ \\
\hline $\begin{array}{l}\text { Nilasena, } 1995 \\
\text { [24] }\end{array}$ & 7 & $\begin{array}{l}\text { Reminders for preventive } \\
\text { care activities in diabetic }\end{array}$ & $2 / 35^{*} / 164$ & $\begin{array}{l}\text { Compliance with } \\
\text { preventive care guidelines. }\end{array}$ & 0 & $\ldots$ & $\ldots$ \\
\hline
\end{tabular}


Table 1 Results for CCDSS trials of chronic disease management (Continued)

\begin{tabular}{|c|c|c|c|c|c|c|c|}
\hline $\begin{array}{l}\text { Mazzuca, } 1990 \\
\text { [25] }\end{array}$ & 7 & $\begin{array}{l}\text { Reminders generated from } \\
\text { the medical record system } \\
\text { and placed in patients' } \\
\text { clinic records for the } \\
\text { management of non-insulin } \\
\text { dependent diabetes } \\
\text { mellitus in outpatients. }\end{array}$ & $4^{*} / 114 / 279$ & $\begin{array}{l}\text { Adherence to five } \\
\text { recommendations for care } \\
\text { of non-insulin dependent } \\
\text { diabetes ( } \mathrm{HbA}_{1 c} \text { and fasting } \\
\text { blood glucose laboratory } \\
\text { orders, start home } \\
\text { monitoring of blood } \\
\text { glucose, diet clinic referral, } \\
\text { and start oral } \\
\text { hypoglycaemic therapy). }\end{array}$ & 0 & $\ldots$ & $\cdots$ \\
\hline $\begin{array}{l}\text { Thomas, } 1983 \\
{[26]}\end{array}$ & 2 & $\begin{array}{l}\text { Recommendations for test } \\
\text { ordering, prescribing, and } \\
\text { early diagnosis for } \\
\text { ambulatory patients in } \\
\text { primary care. }\end{array}$ & $1 / \ldots / 185^{*}$ & Diabetic clinic visits. & 0 & $\begin{array}{l}\text { Emergency department } \\
\text { visits; hospitalizations and } \\
\text { time hospitalized; BP and } \\
\text { glucose levels; obesity. }\end{array}$ & $\cdots$ \\
\hline \multicolumn{8}{|c|}{ Diabetes and Other } \\
\hline $\begin{array}{l}\text { Derose, } 2005 \\
{[27]}\end{array}$ & 7 & $\begin{array}{l}\text { Recommendations for } \\
\text { prescription of ACE-IS, ARBs, } \\
\text { and statins in outpatients } \\
\text { with diabetes or } \\
\text { atherosclerosis. }\end{array}$ & $\begin{array}{l}\ldots / 1089 / \\
8,557^{*}\end{array}$ & $\begin{array}{l}\text { Appropriate prescription of } \\
\text { ACE-Is, ARBs, or statins } \\
\text { within two weeks after } \\
\text { patient visit. }\end{array}$ & + & $\ldots$ & ... \\
\hline $\begin{array}{l}\text { Sequist, } 2005 \\
{[28]}\end{array}$ & 6 & $\begin{array}{l}\text { Reminders, based on } \\
\text { evidence-based guidelines, } \\
\text { for management of } \\
\text { diabetes and coronary } \\
\text { artery disease in primary } \\
\text { care. }\end{array}$ & $\begin{array}{l}20 * / 194 / \\
6,243\end{array}$ & $\begin{array}{l}\text { Receipt of recommended } \\
\text { care for diabetes } \\
\text { (cholesterol, } \mathrm{HbA}_{1 \mathrm{c}} \text { and } \\
\text { dilated eye exams, and use } \\
\text { of ACE-Is or statins) or } \\
\text { coronary artery disease } \\
\text { (cholesterol exam and use } \\
\text { of aspirin, beta-blockers, } \\
\text { and statins). }\end{array}$ & + & $\ldots$ & $\cdots$ \\
\hline Martin, 2004[29] & 8 & $\begin{array}{l}\text { Alerts for management of } \\
\text { elderly patients in a health } \\
\text { maintenance organization } \\
\text { setting. }\end{array}$ & $\begin{array}{l}\ldots * \text { * } / 104 / \\
8,504\end{array}$ & $\begin{array}{l}\text { Disenrollment from Health } \\
\text { Management Organization } \\
\text { plan; patient satisfaction } \\
\text { with health plan. }\end{array}$ & + & $\begin{array}{l}\text { General health (SF-36 } \\
\text { score); inpatient and skilled } \\
\text { nursing facility admissions. }\end{array}$ & 0 \\
\hline $\begin{array}{l}\text { Demakis, } 2000 \\
{[30]}\end{array}$ & 7 & $\begin{array}{l}\text { Reminders for screening, } \\
\text { monitoring, and } \\
\text { counselling in accordance } \\
\text { with predefined standards } \\
\text { of care in ambulatory care. }\end{array}$ & $\begin{array}{l}12 * / 275 / \\
12,989\end{array}$ & $\begin{array}{l}\text { Compliance with } 13 \\
\text { standards of care for } \\
\text { coronary artery disease, } \\
\text { hypertension, diabetes, } \\
\text { smoking cessation, } \\
\text { vaccination, warfarin } \\
\text { treatment monitoring, atrial } \\
\text { fibrillation, myocardial } \\
\text { infarction, and } \\
\text { gastrointestinal bleeding. }\end{array}$ & + & $\ldots$ & .. \\
\hline $\begin{array}{l}\text { Hetlevik, } 1999 \\
\text { [31-33] }\end{array}$ & 8 & $\begin{array}{l}\text { Physician-initiated } \\
\text { guideline-based guidance } \\
\text { for diagnosis and } \\
\text { management of } \\
\text { hypertension, diabetes } \\
\text { mellitus, and } \\
\text { hypercholesterolemia in } \\
\text { primary care. }\end{array}$ & $\begin{array}{l}56 * / 56 / \\
3,273\end{array}$ & $\begin{array}{l}\text { Hypertension and diabetic } \\
\text { patients without recorded } \\
\text { data for BP, serum } \\
\text { cholesterol, BMI, smoking } \\
\text { status, CHD risk score, and } \\
\mathrm{CV} \text { inheritance; diabetic } \\
\text { patients without recorded } \\
\text { data for } \mathrm{HbA}_{1 c} \text { levels. }\end{array}$ & 0 & $\begin{array}{l}\text { SBP and DBP levels; serum } \\
\text { cholesterol levels; BMl; } \\
\text { change in smoking status; } \\
\text { change in CHD risk score } \\
\text { and proportion of patients } \\
\text { with CV inheritance; and, } \\
\text { for diabetic patients, } \mathrm{HbA}_{1 \mathrm{c}} \\
\text { levels. }\end{array}$ & 0 \\
\hline \multicolumn{8}{|c|}{ Hypertension } \\
\hline $\begin{array}{l}\text { Bosworth, } 2009 \\
\text { [34] }\end{array}$ & 9 & $\begin{array}{l}\text { Recommendations for } \\
\text { management of } \\
\text { hypertension in primary } \\
\text { care. }\end{array}$ & $1 * / 32 / 588$ & $\ldots$ & $\cdots$ & Change in BP control. & 0 \\
\hline Hicks, 2008[35] & 7 & $\begin{array}{l}\text { Reminders for } \\
\text { management of } \\
\text { hypertension in adults in } \\
\text { primary care. }\end{array}$ & $\begin{array}{l}14^{*} / \\
\ldots / 2,027\end{array}$ & $\begin{array}{l}\text { Visit-specific adherence to } \\
\text { guideline medication } \\
\text { prescribing. }\end{array}$ & + & Patients with controlled BP. & 0 \\
\hline
\end{tabular}


Table 1 Results for CCDSS trials of chronic disease management (Continued)

\begin{tabular}{|c|c|c|c|c|c|c|c|}
\hline $\begin{array}{l}\text { Borbolla, } 2007 \\
{[36]}\end{array}$ & 7 & $\begin{array}{l}\text { Recommendations for } \\
\text { monitoring of BP in } \\
\text { outpatients and primary } \\
\text { care patients with chronic } \\
\text { disease. }\end{array}$ & $\begin{array}{l}. . / 182^{*} / \\
2,315\end{array}$ & $\begin{array}{l}\text { BP measurement for } \\
\text { appropriate patients. }\end{array}$ & + & Mean SBP and DBP. & 0 \\
\hline $\begin{array}{l}\text { Mitchell, } 2004 \\
\text { [37] }\end{array}$ & 7 & $\begin{array}{l}\text { Feedback for identification, } \\
\text { treatment, and control of } \\
\text { hypertension in elderly } \\
\text { patients in primary care. }\end{array}$ & $\begin{array}{l}52 * / \\
. . / 30,345\end{array}$ & $\begin{array}{l}\text { Patients without BP } \\
\text { measurements. }\end{array}$ & 0 & $\begin{array}{l}\text { SBP levels; patients with } \\
\text { controlled hypertension. }\end{array}$ & 0 \\
\hline $\begin{array}{l}\text { Murray, } 2004 \\
{[38]}\end{array}$ & 5 & $\begin{array}{l}\text { Treatment } \\
\text { recommendations for } \\
\text { management of } \\
\text { hypertension in primary } \\
\text { care. }\end{array}$ & $4 / \ldots * / 712$ & $\begin{array}{l}\text { Compliance with } \\
\text { antihypertensive drug } \\
\text { recommendations; patient } \\
\text { satisfaction with physicians } \\
\text { and pharmacists. }\end{array}$ & 0 & $\begin{array}{l}\text { Quality of life measured } \\
\text { using SF- } 36 \text { and a locally } \\
\text { validated generic quality of } \\
\text { life indicator. }\end{array}$ & 0 \\
\hline $\begin{array}{l}\text { Montgomery, } \\
\text { 2000[39] }\end{array}$ & 10 & $\begin{array}{l}\text { Computer support system } \\
\text { provided patient-specific } \\
\text { five-year CV risk for } \\
\text { management of } \\
\text { hypertension in primary } \\
\text { care. }\end{array}$ & $27^{*} / 85 / 614$ & $\begin{array}{l}\text { Number of patients } \\
\text { prescribed CV drugs. }\end{array}$ & 0 & Five-year CV risk; SBP; DBP. & 0 \\
\hline Rossi, 1997[40] & 9 & $\begin{array}{l}\text { Reminders to modify drug } \\
\text { therapy in hypertensive } \\
\text { outpatients receiving } \\
\text { calcium channel blockers. }\end{array}$ & $1 / 71 / 719^{*}$ & $\begin{array}{l}\text { Prescription changes from } \\
\text { a calcium channel blocker } \\
\text { to another antihypertensive } \\
\text { agent. }\end{array}$ & + & & ... \\
\hline $\begin{array}{l}\text { McAlister, } 1986 \\
\text { [41] }\end{array}$ & 7 & $\begin{array}{l}\text { Feedback to physicians for } \\
\text { management of } \\
\text { hypertension in primary } \\
\text { care. }\end{array}$ & $\begin{array}{l}50 / 50 * / \\
2,231\end{array}$ & $\begin{array}{l}\text { Length of follow up; } \\
\text { number of office visits; } \\
\text { patients treated for } \\
\text { hypertension. }\end{array}$ & 0 & $\begin{array}{l}\text { Patients with DBP } \leq 90 \\
\mathrm{mmHg} \text {; duration of DBP } \\
\leq 90 \mathrm{mmHg} \text {; change in } \\
\text { DBP. }\end{array}$ & 0 \\
\hline $\begin{array}{l}\text { Rogers, } 1984 \\
{[42-44]}\end{array}$ & 4 & $\begin{array}{l}\text { Detection of deficiencies in } \\
\text { care and recommendations } \\
\text { for the management of } \\
\text { hypertension, obesity and } \\
\text { renal disease in outpatients. }\end{array}$ & $1 / \ldots / 484^{*}$ & $\begin{array}{l}\text { Patients with hypertension } \\
\text { given renal function, } \\
\text { potassium, or fundoscopic } \\
\text { exams, or intravenous } \\
\text { pyelograms; number of } \\
\text { diets given to or reviewed } \\
\text { with obesity patients; } \\
\text { patients with renal disease } \\
\text { given renal function exams, } \\
\text { urine analysis, or urine } \\
\text { culture; perceived quality of } \\
\text { communication. }\end{array}$ & + & Perceived health status. & + \\
\hline Coe, 1977[45] & 4 & $\begin{array}{l}\text { Recommendations for } \\
\text { management of } \\
\text { hypertension medication in } \\
\text { patients attending } \\
\text { hypertension clinics. }\end{array}$ & $2 / \ldots / 116^{*}$ & $\ldots$ & $\ldots$ & Adequate BP control. & 0 \\
\hline \multicolumn{8}{|c|}{ Asthma and COPD } \\
\hline Fiks, 2009[46] & 8 & $\begin{array}{l}\text { Alerts for influenza } \\
\text { vaccination for children } \\
\text { and adolescents with } \\
\text { asthma in primary care. }\end{array}$ & $\begin{array}{l}20 * / \\
\ldots / 11,919\end{array}$ & $\begin{array}{l}\text { Captured opportunities for } \\
\text { vaccination; up-to-date } \\
\text { vaccination rates (adjusted } \\
\text { analysis). }\end{array}$ & 0 & $\ldots$ & ... \\
\hline Poels, 2009[47] & 10 & $\begin{array}{l}\text { Presentation of data to } \\
\text { assist in the diagnosis and } \\
\text { management of chronic } \\
\text { airway diseases in primary } \\
\text { care. }\end{array}$ & $44^{*} / . . / 868$ & Change in diagnoses. & 0 & $\ldots$ & ... \\
\hline $\begin{array}{l}\text { Martens, } 2007 \\
{[48,49]}\end{array}$ & 9 & $\begin{array}{l}\text { Recommendations for } \\
\text { appropriate use of } \\
\text { antibiotics and } \\
\text { management of asthma, } \\
\text { COPD, and dyslipidemia. }\end{array}$ & $\begin{array}{l}23 * / 53 / \\
3,496\end{array}$ & $\begin{array}{l}\text { Appropriate prescribing or } \\
\text { lack of prescribing of drugs. }\end{array}$ & 0 & $\ldots$ & ... \\
\hline Kattan, 2006[50] & 8 & $\begin{array}{l}\text { Recommendations for } \\
\text { management of drug } \\
\text { therapy in severe asthma in } \\
\text { paediatric outpatients. }\end{array}$ & $\begin{array}{l}. . / 435 / \\
937^{*}\end{array}$ & $\begin{array}{l}\text { Time to appropriate } \\
\text { medication step-up; } \% \text { of } \\
\text { scheduled visits within } 2 \\
\text { months of medication step- } \\
\text { up recommendation. }\end{array}$ & + & $\begin{array}{l}\text { Symptom days every } 2 \\
\text { weeks. }\end{array}$ & 0 \\
\hline
\end{tabular}


Table 1 Results for CCDSS trials of chronic disease management (Continued)

\begin{tabular}{|c|c|c|c|c|c|c|c|}
\hline $\begin{array}{l}\text { Kuilboer, } 2006 \\
{[51]}\end{array}$ & 10 & $\begin{array}{l}\text { Recommendations for } \\
\text { monitoring and treatment } \\
\text { of asthma and COPD in } \\
\text { primary care. }\end{array}$ & $\begin{array}{l}32 * / 40 / \\
156,772\end{array}$ & $\begin{array}{l}\text { Contact frequency; peak } \\
\text { flow and FEV1 } \\
\text { measurements; number of } \\
\text { prescriptions for respiratory } \\
\text { drugs. }\end{array}$ & 0 & $\ldots$ & ... \\
\hline Plaza, 2005[52] & 9 & $\begin{array}{l}\text { Guideline-based } \\
\text { recommendations to } \\
\text { general practitioners and } \\
\text { pneumologists for cost- } \\
\text { effective management of } \\
\text { asthma in primary care. }\end{array}$ & .../20*/198 & $\begin{array}{l}\text { Health resource use } \\
\text { (spirometry, blood tests, } \\
\text { total immunoglobulin } \mathrm{E}_{\text {, }} \\
\text { skin allergy tests, thorax } \\
\text { radiography, and oral } \\
\text { glucocorticoid } \\
\text { prescriptions); medical } \\
\text { visits; home visits; visits to } \\
\text { other physicians. }\end{array}$ & 0 & $\begin{array}{l}\text { St. George Respiratory } \\
\text { Questionnaire total score. }\end{array}$ & + \\
\hline $\begin{array}{l}\text { Tierney, } 2005 \\
{[53]}\end{array}$ & 9 & $\begin{array}{l}\text { Recommendations for the } \\
\text { management of asthma } \\
\text { and COPD in adults in } \\
\text { primary care. }\end{array}$ & $4 / 266^{*} / 706$ & $\begin{array}{l}\text { Adherence to management } \\
\text { recommendations. }\end{array}$ & 0 & $\begin{array}{l}\text { SF-36 subscale scores; } \\
\text { McMaster Asthma Quality } \\
\text { of Life Questionnaire } \\
\text { scores; McMaster Chronic } \\
\text { Respiratory Disease } \\
\text { Questionnaire scores; } \\
\text { emergency department } \\
\text { visits; hospitalizations. }\end{array}$ & 0 \\
\hline $\begin{array}{l}\text { Eccles, } 2002 \\
{[54,55]^{b}}\end{array}$ & 10 & $\begin{array}{l}\text { Care recommendations for } \\
\text { management of asthma } \\
\text { and angina in adults in } \\
\text { primary care. }\end{array}$ & $\begin{array}{l}62 * / \\
\ldots / 4,506\end{array}$ & $\begin{array}{l}\text { Adherence to guideline } \\
\text { recommendations for } \\
\text { angina (record BP, 12-lead } \\
\text { and exercise } \\
\text { electrocardiogram, Hb and } \\
\text { lipid levels, blood glucose } \\
\text { levels, thyroid function, and } \\
\text { record or provide advice } \\
\text { for exercise, weight, and } \\
\text { smoking) and medications } \\
\text { prescribed for angina; } \\
\text { adherence to guideline } \\
\text { recommendations for } \\
\text { asthma (assessment of lung } \\
\text { function, compliance, } \\
\text { inhaler technique, and } \\
\text { smoking status, and } \\
\text { provision of asthma } \\
\text { education, action plan, } \\
\text { smoking cessation advice, } \\
\text { or nicotine replacement } \\
\text { therapy) and prescription of } \\
\text { drugs for asthma. }\end{array}$ & 0 & $\begin{array}{l}\text { Quality of life (SF-36 and } \\
\text { EQ-5D questionnaires); } \\
\text { disease-specific quality of } \\
\text { life (Seattle angina } \\
\text { questionnaire, Newcastle } \\
\text { asthma symptoms } \\
\text { questionnaire, and the } \\
\text { asthma quality of life } \\
\text { questionnaire); angina or } \\
\text { asthma consultations. }\end{array}$ & 0 \\
\hline $\begin{array}{l}\text { McCowan2001 } \\
{[56]}\end{array}$ & 8 & $\begin{array}{l}\text { Guideline-based } \\
\text { recommendations for } \\
\text { management of asthma in } \\
\text { primary care. }\end{array}$ & $. . . * / 46 / 477$ & $\begin{array}{l}\text { Practice initiated reviews; } \\
\text { peak flow meters issued; } \\
\text { self-management plans } \\
\text { used; symptom } \\
\text { assessments; prescriptions } \\
\text { for oral corticosteroids and } \\
\text { emergency nebulizations. }\end{array}$ & 0 & $\begin{array}{l}\text { Acute asthma } \\
\text { exacerbations; patient- } \\
\text { initiated primary care } \\
\text { consultations. }\end{array}$ & + \\
\hline \multicolumn{8}{|c|}{ Dyslipidemia } \\
\hline $\begin{array}{l}\text { Bertoni, } 2009 \\
{[57,58]}\end{array}$ & 9 & $\begin{array}{l}\text { Recommendations for } \\
\text { guideline-consistent } \\
\text { screening and treatment of } \\
\text { dyslipidemia in primary } \\
\text { care. }\end{array}$ & $\begin{array}{l}59 * / \\
\ldots / 3,821\end{array}$ & $\begin{array}{l}\text { Change from baseline in } \\
\text { number of patients with } \\
\text { appropriate lipid } \\
\text { management (based on } \\
\text { LDL-C and risk strata). }\end{array}$ & + & $\ldots$ & .. \\
\hline Gilutz, 2009[59] & 7 & $\begin{array}{l}\text { Reminders for monitoring } \\
\text { and treatment of patients } \\
\text { previously hospitalized with } \\
\text { coronary artery disease and } \\
\text { followed up in primary } \\
\text { care. }\end{array}$ & $\begin{array}{l}112^{*} / 600 / \\
7,448\end{array}$ & $\begin{array}{l}\text { Appropriate initiation, up- } \\
\text { titration, or continuation of } \\
\text { statin therapy; rate of } \\
\text { adequate lipoprotein } \\
\text { monitoring. }\end{array}$ & + & Reduction in LDL-C. & + \\
\hline $\begin{array}{l}\text { Lester, } 2006 \\
{[60,61]}\end{array}$ & 8 & $\begin{array}{l}\text { Recommendations, based } \\
\text { on evidence-based } \\
\text { guidelines, for the } \\
\text { management of patients at } \\
\text { high risk for hyperlipidemia } \\
\text { in primary care. }\end{array}$ & $1 / 14 / 235^{*}$ & $\begin{array}{l}\text { Patients with changes in } \\
\text { statin prescriptions at } 1 \\
\text { month and } 12 \text { months. }\end{array}$ & + & Change in LDL-C. & 0 \\
\hline
\end{tabular}


Table 1 Results for CCDSS trials of chronic disease management (Continued)

\begin{tabular}{lll}
\hline Cobos, 2005[62] $\quad 10$ & Recommendations for & $42 * /$ \\
& hypercholesterolemia & $. . / 2,221$ \\
& therapy, follow-up visit & \\
& frequency, and laboratory \\
& test ordering for patients \\
& with hypercholesterolemia \\
& in primary care.
\end{tabular}

Number of scheduled

physician visits and patient

assessments (lipids,

aspartate or alanine

aminotransferase, or

creatine kinase); number of

patients treated with lipid-

lowering drugs.

\begin{tabular}{llll}
\hline & & \multicolumn{1}{c}{ Cars } \\
\hline Goud, 2009 & 8 & Recommendations for & $35^{*} / 50 /$ \\
{$[63,64]$} & & guideline-consistent care & 2,787 \\
& $\begin{array}{l}\text { plans for outpatient cardiac } \\
\text { rehabilitation. }\end{array}$
\end{tabular}

Feldman, 2005

$[65,66]$

9

Recommendations for nurse-coordinated .../354*/ 628 management of patients with heart failure receiving home care.

Tierney, 2003

10

[67]

Eccles, 2002

$[54,55]^{b}$

recommendations for management of heart disease in primary care.

$62 * /$ management of asthma

\section{Cardiac Care}

Compliance with guideline

recommendations for

exercise training, education

therapy, relaxation therapy,

and lifestyle change

therapy.

Patient adherence to self-

management indicators

(taking and recognizing

medications, salting food,

and weighing behavior),

home-care related visits,

and outpatient doctor

visits.

4*/115/706 Adherence with cardiac

care recommendations. and angina in adults in primary care.
Adherence to guideline recommendations for angina (record BP, 12-lead and exercise

electrocardiogram, $\mathrm{Hb}$ and lipid levels, blood glucose levels, thyroid function, and record or provide advice for exercise, weight, and smoking) and medications prescribed for angina; adherence to guideline recommendations for asthma (assessment of lung function, compliance, inhaler technique, and smoking status, and provision of asthma education, action plan, smoking cessation advice, or nicotine replacement therapy) and prescription of drugs for asthma.
$0 \quad$ Patients successfully managed according to CV risk level assessed by LDL-C levels or maintenance of $\mathrm{CV}$ risk level.

\section{Other}

\begin{tabular}{lll}
\hline Lee, 2009[68,69] $6 \quad$ & Recommendations for & $\ldots / 29^{*} /$ \\
& screening, diagnosis and & 1,874 \\
& obesity care planning in \\
& acute and primary care.
\end{tabular}

Encounters with obesityrelated diagnoses or missing obesity-related diagnoses, and obesity -related diagnoses not screened and entered in cCDSS.

Locatelli, $2009 \quad 8 \quad$ Recommendations for [70] management of chronic kidney disease in nephrology units.
Patient-specific recommendations for detecting and correcting medical errors in a health maintenance organization setting.
$53 * / . . / 599$ Use of iron therapy or erythropoetic therapy: guideline-adherent treatment.

1/1378/ $49,988^{*}$

Resolution rate for identified problems (add a drug, do a test, or stop a drug).
0 Kansas City

Cardiomyopathy

Questionnaire and EuroQoL

EQ-5D scale scores;

depression (Geriatric

Depression Scale); service

use (hospitalizations, inpatient nights, and emergency department visits)

0 Quality of life (SF-36 scale and chronic heart disease questionnaire).

0 Quality of life (SF-36 and EQ-5D questionnaires); disease-specific quality of life (Seattle angina questionnaire, Newcastle asthma symptoms questionnaire, and the asthma quality of life questionnaire); angina or asthma consultations. 
Table 1 Results for CCDSS trials of chronic disease management (Continued)

\begin{tabular}{|c|c|c|c|c|c|c|c|}
\hline $\begin{array}{l}\text { Verstappen } \\
2007[72]\end{array}$ & 6 & $\begin{array}{l}\text { Management of } \\
\text { methotrexate for early } \\
\text { rheumatoid arthritis in } \\
\text { adult outpatients. }\end{array}$ & $6 / . . / 299 *$ & $\ldots$ & .. & $\begin{array}{l}\text { Patients in remission for } \geq 3 \\
\text { months in first two years. }\end{array}$ & + \\
\hline $\begin{array}{l}\text { Downs, } 2006 \\
{[73]}\end{array}$ & 9 & $\begin{array}{l}\text { Prompts for the } \\
\text { investigation and } \\
\text { management of dementia } \\
\text { in primary care. }\end{array}$ & $35 * / \ldots / 450$ & $\begin{array}{l}\text { Detection of dementia; } \\
\text { compliance with diagnostic } \\
\text { guidelines. }\end{array}$ & 0 & $\ldots$ & $\cdots$ \\
\hline $\begin{array}{l}\text { Feldstein, } \\
\text { 2006b[74] }\end{array}$ & 8 & $\begin{array}{l}\text { Guideline-recommended } \\
\text { osteoporosis care for 50-89 } \\
\text { year old women in primary } \\
\text { care who experience a } \\
\text { fracture. }\end{array}$ & $\begin{array}{l}15 / 159 / \\
311^{*}\end{array}$ & $\begin{array}{l}\text { Measurement of bone } \\
\text { mineral density; use of } \\
\text { osteoporosis medication. }\end{array}$ & + & $\begin{array}{l}\text { Caloric expenditure; regular } \\
\text { physical activity; calcium } \\
\text { intake. }\end{array}$ & 0 \\
\hline $\begin{array}{l}\text { McDonald2005 } \\
{[75]}\end{array}$ & 8 & $\begin{array}{l}\text { Recommendations to } \\
\text { home care nurses for } \\
\text { cancer pain assessment } \\
\text { and guideline-based } \\
\text { management. }\end{array}$ & $1 / 336 * / 673$ & $\begin{array}{l}\text { Nurse assessment practices } \\
\text { (pain, medications, mood, } \\
\text { and bowel movement); } \\
\text { nurse instruction practices } \\
\text { (medication and side effect } \\
\text { management, pain } \\
\text { management, contacting } \\
\text { physicians, and education); } \\
\text { cost-effectiveness for } \\
\text { reductions in pain and } \\
\text { hospitalizations. }\end{array}$ & 0 & $\begin{array}{l}\text { Pain; quality of life } \\
\text { (European Organization for } \\
\text { Research and Treatment of } \\
\text { Cancer questionnaire); } \\
\text { symptom management; } \\
\text { cost-effectiveness. }\end{array}$ & 0 \\
\hline $\begin{array}{l}\text { Dexter, } 1998 \\
{[76]}\end{array}$ & 8 & $\begin{array}{l}\text { Reminders to discuss and } \\
\text { complete advanced } \\
\text { directives in outpatients. }\end{array}$ & $\begin{array}{l}4^{*} / 10 / \\
1,042\end{array}$ & $\begin{array}{l}\text { Rate of advance directive } \\
\text { discussions; rate of form } \\
\text { completion. }\end{array}$ & + & $\ldots$ & .. \\
\hline $\begin{array}{l}\text { Rubenstein } 1995 \\
\text { [77] }\end{array}$ & 7 & $\begin{array}{l}\text { Computer-generated } \\
\text { feedback designed to } \\
\text { identify and suggest } \\
\text { management for functional } \\
\text { deficits in primary care. }\end{array}$ & $1 * / 73 / 557$ & $\begin{array}{l}\text { Clinical problems listed at } \\
\text { visits; functional status } \\
\text { interventions for patients } \\
\text { with functional status } \\
\text { problems; physician } \\
\text { attitudes toward managing } \\
\text { functional status. }\end{array}$ & $\cdots$ & $\begin{array}{l}\text { Functional status (basic and } \\
\text { intermediate activities of } \\
\text { daily living, mental health, } \\
\text { social activities, and work } \\
\text { performance); specific } \\
\text { impairments (physical, } \\
\text { psychological, or social } \\
\text { function). }\end{array}$ & 0 \\
\hline $\begin{array}{l}\text { Petrucci, } 1991 \\
\text { [78] }\end{array}$ & 6 & $\begin{array}{l}\text { Recommendations for } \\
\text { nurse management of } \\
\text { urinary incontinence in } \\
\text { elderly patients in nursing } \\
\text { homes. }\end{array}$ & $\ldots *$.. & $\begin{array}{l}\text { Nurses' knowledge about } \\
\text { urinary incontinence care. }\end{array}$ & + & Wet occurrences. & + \\
\hline $\begin{array}{l}\text { McDonald } 1984 \\
{[79]}\end{array}$ & 6 & $\begin{array}{l}\text { Reminders for } \\
\text { management of } \\
\text { outpatients, including } \\
\text { cancer screening, } \\
\text { vaccinations, and weight } \\
\text { reduction counselling. }\end{array}$ & $\begin{array}{l}1 * / 130 / \\
12,467\end{array}$ & $\begin{array}{l}\text { Rate of clinician response } \\
\text { to indications for care } \\
\text { actions. }\end{array}$ & + & $\begin{array}{l}\text { Hospitalizations; emergency } \\
\text { room and clinic visits; and } \\
\text { time averaged values for } \\
\text { DBP/SBP; weight; serum } \\
\text { glucose; serum Hb; serum } \\
\text { potassium; blood urea } \\
\text { nitrogen. }\end{array}$ & 0 \\
\hline
\end{tabular}

Abbreviations: ACE -I, angiotensin converting enzyme inhibitor; ARB, angiotensin receptor blockers; BMl, body mass index; BP, blood pressure; CCDSS, computerized clinical decision support system; CHD, coronary heart disease; COPD, chronic obstructive pulmonary disease; CV, cardiovascular; DBP, diastolic blood pressure; $\mathrm{Hb}$, haemoglobin; LDL, low-density lipoprotein; SBP, systolic blood pressure.

*Unit of allocation.

${ }^{a}$ Outcomes are evaluated for effect as positive (+) or negative (-) for CCDSS, or no effect (0), based on the following hierarchy. An effect is defined as $\geq 50 \%$ of relevant outcomes showing a statistically significant difference $(2 p<0.05)$ :

1. If a single primary outcome is reported, in which all components are applicable, this is the only outcome evaluated.

2. If $>1$ primary outcome is reported, the $\geq 50 \%$ rule applies and only the primary outcomes are evaluated.

3. If no primary outcomes are reported (or only some of the primary outcome components are relevant) but overall analyses are provided, the overall analyses are evaluated as primary outcomes. Subgroup analyses are not considered.

4. If no primary outcomes or overall analyses are reported, or only some components of the primary outcome are relevant for the care area, any reported prespecified outcomes are evaluated.

5. If no clearly prespecified outcomes are reported, any available outcomes are considered.

6. If statistical comparisons are not reported, 'effect' is designated as not evaluated (...).

${ }^{\text {b }}$ Study included in two categories. 


\section{CCDSS and study characteristics}

Additional file 2, Table S2 describes CCDSS design and implementation characteristics. Denominators vary because not all trials reported on all features considered. Fifty-nine percent $(32 / 54)$ of CCDSSs were integrated with electronic medical records $[2,3,14-18,21-23,25$, $26,28,29,31-40,42-44,46,48,49,51,53-55,60-64,67,73,74,76-$ ,79], and $17 \%(8 / 47)$ were also integrated with computerized physician order entry systems [22,29,36, $38,46,48,49,53,60,61]$. Fifty-three percent $(25 / 47)$ automatically obtained data needed to give recommendations from electronic medical records $[2,3,18,21-23,25$, 28,34-36,38,40,46,48,49,51,53-55,60-64,67,73,74,76,79]; $36 \%(17 / 47)$ relied on practitioners to enter the data [2,3,14-17,23,30,39,41,45,48,49,52-58,67-69,72,75]; and $26 \%(12 / 47)$ used research staff for this purpose $[18,24,36,41,47,50,59,65,66,72,75,77,79]$. Advice was provided at the time of care in $85 \%$ of trials $(46 / 54)$ [2,3,13-18,20-28,30-36,38-40,42-49,51-59,62-70,73-79] most often on a desktop or laptop computer (51\%; 26/ 51) $[2,3,14-17,21,22,28,30,34-39,46-49,51,53-56,62-64,67$, $70,72-74]$ or by existing non-prescribing staff $(22 \%$; $11 /$ 51) $[18,23-26,30,40,42-44,71,76,79]$. Fifty-three percent $(29 / 54)$ provided advice to other healthcare practitioners in addition to physicians $[2,3,11,12,14-18,22,23,25,26$, $28-36,38,40,45-47,53,57-59,63,64,67,71,73,76,77,79]$ and $15 \%(8 / 55)$ directly advised patients in addition to practitioners [2,3,11-13,18,19,29,41,74]. Sixty-four percent $(25 / 39)$ of systems were pilot tested [11-19,22,23,26,28, $31-34,36,37,39,46,47,50,51,56,59-61,63,64,67,72,77]$ and healthcare professionals were trained to use them in $72 \%(34 / 47)[2,3,11-17,19-22,25,29-33,35,36,38,39,46-61$, $63,64,67-69,73,77,78]$. Reports rarely described the CCDSS user interface characteristics.

Seventy-three percent of trials (40/55) declared that at least one author was involved in the development of the system

$[2,3,11-13,18,19,22-26,28,30,34,36,38-51,53-61,63,64,67--$ $70,72,73,76,77,79]$ and three trials indicated that all authors were independent of development [14-17, 31-33,78].

Additional file 3, Table S3 provides further details of the CCDSS intervention, care setting, study funding source, and year of publication. Trials included a total of 7,335 practitioners (median, 72; ranging from 5 to 1,378 [when reported]) caring for 381,562 patients (median, 719; ranging from 27 to 156,772 [when reported]) in 974 clinics (median, 13; ranging from 1 to 112 [when reported]) across 705 distinct sites (median, 4; ranging from 1 to 112 [when reported]). Eight trials did not report their source of funding [21,26,36, $40,71-73,75]$. Of the remaining $47,74 \%(\mathrm{n}=35)$ were publicly funded, $17 \%(n=8)$ were conducted with only private funds, [14-17,19,27,48,49,52,60-62,70], and 9\% (n
$=4$ ) were conducted with a combination of private and public funding $[20,29,54,55,75]$. The earliest trial was published in 1977 [45], but over one-half (62\%) were published after our previous search in September 2004 [2,3,11-20,27-29,34-37,46-53,57-66,68-75].

\section{CCDSS effects}

Table 1 summarizes the effects of all systems for improving process of care and patient outcomes and Additional file 4, Table S4 provides further detail regarding systems and individual outcomes selected for evaluation.

Eighty-seven percent (48/55) of trials measured effects on chronic disease management processes $[2,3,11,12$, 14-19,21-33,35-44,46-69,71,73-76,78,79], and 52\% (25/ 48) demonstrated improvement $[2,3,11,12,18,19$, $21,23,27-30,35,36,40,42-44,50,57-61,63,64,68,69,71,73,74-$ ,76,78,79]. Sixty-five percent (36/55) measured impact on patient outcomes [2,3,11-20,22,29,31-39, $41-45,50,52-56,59-62,65-67,70,72,74,75,77-79]$ and $31 \%$ $(11 / 36)$ of these demonstrated benefit on measures such as health-related quality of life, rates of hospitalization, unscheduled care visits, and a host of disease-specific clinical outcomes [2,3,13,18-20,42-44,52,56,59,72,78].

\section{Diabetes}

Thirteen trials described systems primarily supporting diabetes care (median quality score, 7; ranging from 2 to 10) $[2,3,11-26]$. Fifty-five percent (6/11) reported improvements in processes of care including treatment and monitoring $[2,3,11,12,18,19,21,23]$, while $62.5 \%(5 / 8)$ reported improvements in corresponding patient outcomes including blood pressure, $\mathrm{HbA}_{1 \mathrm{c}}$, and low-density lipoprotein (LDL) cholesterol $[2,3,13,18-20]$. The seven trials published since 2005 appeared to show success more consistently: four of five improved the process of care $[2,3,11-13,18-20]$, and five of seven improved patient outcomes [2,3,13,18-20].

Systems in five diabetes trials targeted patients in addition to practitioners $[2,3,11-13,18,19]$. Of these, all four trials that measured process effects demonstrated benefit $[2,3,11,12,18,19]$, and four reported improvement in patient outcomes $[2,3,13,18,19]$.

Several recent trials were conducted in primary community clinics whereas most previous trials were conducted in hospitals. For example, in two trials conducted across multiple practices, CCDSSs provided patient-specific reminders during visits and notified at-risk patients of their care targets and upcoming appointments $[2,3,11,18]$. Both trials demonstrated improvements in composite process measures comprising timely completion of foot and eye exams, and monitoring of blood pressure, $\mathrm{HbA}_{1 \mathrm{c}}$, lipoproteins, and renal function. Both trials also 
showed improvements in corresponding composite patient outcomes.

\section{Diabetes and other conditions}

CCDSSs in five trials (median score, 7; ranging from 6 to 8) provided recommendations for a host of conditions in conjunction with diabetes, including dyslipidemia, hypertension, obesity, and heart failure [27-33]. Their effects on diabetes outcomes could not be isolated. All five measured process of care, and $80 \%(4 / 5)$ found improvements [27-30]. Only one measured corresponding patient outcomes, but showed no benefit [31-33].

\section{Hypertension}

The 10 trials focusing primarily on hypertension management (median score, 7; ranging from 4 to 10) were older, with 70\% (7/10) published before 2005 [34-45].

Eight of 10 trials assessed impact on process of care using measures such as adherence to recommendations for blood pressure control [35-44], patient satisfaction, and number of scheduled care visits, and four demonstrated improvements [35,36,40,42-44].

In contrast to diabetes systems, however, hypertension systems showed little or no patient benefit. Of the nine trials that reported patient outcomes, such as blood pressure and health-related quality of life [34-39,41-45], only one found benefit [42-44]. This multi-component system improved patients' perceived health status by giving suggestions for the management of hypertension, obesity, and renal disease. The trial, however, was of poor quality (methods score 4), and the nature of the intervention prevented isolating effects related to hypertension.

\section{Dyslipidemia}

Four trials evaluated systems that focused primarily on dyslipidemia [57-62]. All were conducted in primary care settings and published after 2005 (median quality score, 8.5; ranging from 7 to 10 ).

Three trials measured effects on process of care and demonstrated improvements in lipid monitoring and treatment [57-61], but only one of three trials measuring patient outcomes found a benefit [59]. This CCDSS generated patient-specific reminders that were mailed to primary care physicians and nurses; highlighted the patient's risk factors, lipoprotein values, and current medications; and recommended initiation or adjustment of lipid-lowering treatment when appropriate. The trial detected improvements in blood lipid monitoring and treatment management, as well as relative reductions in patients' LDL cholesterol.

\section{Asthma and chronic obstructive pulmonary disease (COPD)}

The nine trials of systems supporting asthma care were of excellent quality (median score, 9; ranging from 8 to 10) and relatively new (7/9 published after September 2004), but the systems were generally ineffective [46-56]. All trials measured effects on process of care (including rates of spirometry, thorax radiography, IgE levels, and allergy testing; medication prescriptions and influenza vaccinations; and use of rescue medications) but only one demonstrated benefit [50].

Two of five trials measuring patient outcomes found an impact $[52,56]$. One system delivered asthma recommendations in primary care, made prognostic predictions by matching patients to similar known cases, and allowed users to print self-management plans for their patients [56]. The trial demonstrated a reduction in acute asthma exacerbations and patient-initiated primary care visits. Another system delivered guideline recommendations to general practitioners and pneumologists, and proved to be more cost effective at improving quality of life than usual asthma care [52].

Three asthma systems also gave advice for management of COPD $[48,49,51,53]$. All of these measured process of care but detected no effects. One trial also measured patient outcomes but did not show benefit [53].

\section{Cardiac care}

Systems in four methodologically strong trials (median score, 9.5; ranging from 8 to 10) focused on heart failure $[65,66]$, cardiac rehabilitation $[63,64]$, ischemic heart disease [67], and angina [54,55]. All measured process of care using adherence to guideline recommendations but only one found benefit $[63,64]$. The CCDSS for cardiac rehabilitation used electronic medical records and needs assessment data to generate recommendations for exercise training, education, lifestyle change, and stress management $[63,64]$. The trial demonstrated improved guideline adherence, but patient outcomes were not studied. The other three trials measured effects on quality of life as a patient outcome, but none found benefit [54,55,65-67].

\section{Other care}

We did not group the remaining 12 trials due to their diverse primary indications. They focused on urinary incontinence [78], cancer [75], osteoporosis [74], renal disease [70], functional deficits [77], obesity [68,69], dementia [73], rheumatoid arthritis [72], advance directives [76], and various non-specific indications [71,79]. Most trials found improvements in care process but only two demonstrated benefit to patients: one reduced urinary incontinence in nursing home patients [78], and 
the other improved likelihood of remission in patients with early rheumatoid arthritis through CCDSS-guided management of methotrexate [72].

\section{Costs and practical process related outcomes}

Four trials used cost-effectiveness as an outcome (see Additional file 4, Table S4) [14-17,52,65,66,75]. Only one trial demonstrated improvement to patient outcomes overall, and the CCDSS was also more cost-effective than usual asthma care [52].

Additional file 5, Table S5 summarizes cost-related findings of the 12 trials that statistically compared costs of care between the study groups: six reported no difference with CCDSS compared to usual care [14-17,29,38,52,67,75], four reported savings with the CCDSS $[11,12,50,62,71]$, and two reported that the CCDSS increased some costs [65-67].

In addition to process of care and patient outcomes, we looked for effects on user satisfaction and workflow (see Additional file 5, Table S5). Only seven trials reported a formal effort of assessing user satisfaction: 3 found users satisfied overall $[19,28,63,64]$, one found them unsatisfied [54,55], and the remaining three showed mixed results $[2,3,31-33,56]$. The authors of five other studies commented that users were satisfied in informal evaluations [13,18,36,59,72].

Two trials made formal attempts to measure systems' impact on user workflow and reported mixed results $[23,63,64]$.

\section{Discussion}

This review was done in partnership with key decision makers to summarize the effectiveness of clinical decision support technology for the management of chronic conditions. We considered studies 'positive' if they showed a statistically significant improvement in at least $50 \%$ of relevant outcomes. CCDSSs often improved the process of patient care. When assessed, effects on any patient outcomes were rarely found, but may have been underestimated: $56 \%$ of trials reporting these outcomes declared them primary [11-20,22,29,34,35,38,50,52,56,59-62,67,70,72], and the remaining trials may not have been large enough or long enough to detect such outcomes. No study showed convincing evidence of benefit for major patient outcomes.

Nevertheless, results from recent diabetes management trials are encouraging. Several of these systems were deployed in general community practice and those that engaged both patients and providers were consistently effective. These systems may become increasingly popular with the advent of patient-controlled electronic medical records. Systems addressing several conditions, including but not limited to diabetes, generally improved care but only one measured patient outcomes [31-33] (no effect). In dyslipidemia, systems improved lipid monitoring and treatment, but only one reduced blood lipids [59]. The few dyslipidemia trials were recent and may represent a promising area for future research.

Conversely, most trials in hypertension measured patient outcomes and almost never found benefits, and only some showed improvements in the process of care. Asthma and COPD systems mostly failed to show effectiveness, despite being tested in recent, high-quality trials. The small collection of trials in heart failure, ischemic heart disease, cardiac rehabilitation, and angina also rarely show effects, with improvement only in rehabilitation processes. The remaining systems, too diverse to group, often improved care processes but were seldom found to benefit patients.

While systems in diabetes appear to achieve success with respect to patient outcomes more often than systems in asthma and hypertension, we did not pre-specify this comparison and, given the play of chance and many possible confounders, we cannot confidently assert that the pattern is real. It is plausible that the effectiveness of CCDSS recommendations at improving patient outcomes for some indications is limited by the absence of high-quality clinical evidence in that area. Even the most scientifically sound recommendations, however, will fail to improve health outcomes if patients do not adhere to prescribed treatments-a very common problem [80]. Unfortunately, our suggestions regarding the discrepancy remain purely speculative because studies did not explore reasons for failure, and we do not have enough trials to test these hypotheses reliably.

The growing use of CCDSSs and their potential for benefit and harm highlight the importance of evaluating these systems in well-conducted randomized clinical trials. The increase in number and quality of trials is encouraging, but results remain mixed, and few trials investigated the mechanisms behind their findings. Careful description of study and system design in trial reports, as well as assessments of effectiveness and acceptability of system features, would support progress in this area.

CCDSSs may represent a cost-effective way of improving chronic disease outcomes. However, the economic effects of systems are not readily assessed based on available data. The costs of design, local implementation, ongoing maintenance, and user support can be high, and may be further elevated by the unique nature of chronic care. This warrants cost-effectiveness analyses, but only four trials $[14-17,52,65,66,75]$ reported such data and little cost data of any kind are available across studies. If cost savings exist, however, current results suggest that they are modest. 
The benefits we can expect from the use of computerized decision support are not clear. Policy makers promoting the use of CCDSS, as well as healthcare administrators and practitioners considering local implementation, should be aware that the evidence of CCDSS effectiveness is limited, especially with respect to the small number and size of studies of patient outcomes. Further, evidence of benefit comes mainly from a few 'trail blazer' institutions with much in-house informatics expertise, evaluating home-grown systems developed over many years. As a result, trials in this review may not represent the effects in less technically endowed settings or from commercially available systems, the capabilities of which have been shown to vary greatly [81].

Our review has some potential limitations. Great heterogeneity in CCDSS design, purpose, and targets for evaluation prevented us from conducting a meta-analysis. Instead, we used a binary measure of effect, where we considered studies 'positive' if they showed a statistically significant improvement in at least $50 \%$ of relevant outcomes. Thus, some of the studies we considered to show no effect found improvement on a minority of secondary or non-prespecified outcomes. These findings could be real but could also be due to post hoc unplanned analyses and multiple testing. Readers should refer to the Methods section for a more detailed account of our effect assessment.

We were unable to assess the risk of publication bias in this literature. Given that most systems were studied by their own developers, we suspect that publication bias is likely, and even our findings of modest effects may overestimate the true likelihood of seeing benefit from CCDSSs.

Our method of summarizing the evidence by vote counting inflates the risk of Type 2 error [82] and should generally be approached with caution. However, our results remain essentially unchanged from our 2005 review [4] and are comparable to another major review conducted by Kawamoto and colleagues [83], and a recent 'umbrella ' review of high-quality systematic reviews of CCDSSs in hospital settings [84]. Another recent review of reminder systems [5] (a subset of CCDSS) summarized evidence by effect size meta-analysis and qualified the impact of these interventions as falling below the thresholds of clinical importance. Given the similar conclusions of these other systematic reviews and the risk of publication bias in the CCDSS literature, we have little reason to believe that our methods underestimate the benefit from these systems.

Finally, we observed improvements in the quality of trials over time but this trend may have resulted from better reporting in more recent studies.

\section{Conclusions}

CCDSSs can improve chronic disease management processes and, in some cases, patient outcomes. Recent trials in diabetes care show the most promising results. The mechanisms behind systems' success or failure remain understudied. Future trials with clear descriptions of system design, local context, implementation strategy, costs, adverse outcomes, user satisfaction, and impact on user workflow will better inform CCDSS development and decisions about local implementation.

\section{Additional material}

Additional file 1: Table S1. Study methods scores for trials of chronic disease management. Methods scores for the included studies. Additional file 2: Table S2. CCDSS characteristics for trials of chronic disease management. CCDSS characteristics of the included studies.

Additional file 3: Table S3. Study characteristics for trials of chronic disease management. Study characteristics of the included studies.

Additional file 4: Table S4. Results for CCDSS trials of chronic disease management. Details results of the included studies.

Additional file 5: Table S5. Costs and CCDSS process-related outcomes for trials of chronic disease management. Cost and CCDSS process-related outcomes for the included studies.

\section{Acknowledgements}

The research was funded by a Canadian Institutes of Health Research Synthesis Grant: Knowledge Translation KRS 91791. The members of the Computerized Clinical Decision Support System (CCDSS) Systematic Review Team included the Principal Investigator, Co-Investigators, Co-Applicants/ Senior Management Decision-makers, Co-Applicants/Clinical Service Decision-Makers, and Research Staff. The following were involved in collection and/or organization of data: Jeanette Prorok, MSc, McMaster University; Nathan Souza, MD, MMEd, McMaster University; Brian Hemens, BScPhm, MSc, McMaster University; Robby Nieuwlaat, PhD, McMaster University; Shikha Misra, BHSc, McMaster University; Jasmine Dhaliwal, BHSC, McMaster University; Navdeep Sahota, BHSc, University of Saskatchewan; Anita Ramakrishna, BHSc, McMaster University; Pavel Roshanov, BSc, McMaster University; Tahany Awad, MD, McMaster University. Nicholas Hobson, DiplT, Chris Cotoi, BEng, EMBA, and Rick Parrish, DiplT, at McMaster University provided programming and information technology support.

\section{Author details}

${ }^{1}$ Health Research Methodology Program, McMaster University, 1280 Main Street West, Hamilton, ON, Canada. ${ }^{2}$ University of Toronto, 1 Kings College Circle, Toronto, ON, Canada. ${ }^{3}$ Department of Medicine, McMaster University, 1280 Main Street West, Hamilton, ON, Canada. ${ }^{4}$ Hamilton Health Sciences, 1200 Main Street West, Hamilton, ON, Canada. ${ }^{5}$ Department of Medicine, Department of Epidemiology and Biostatistics, University of Western Ontario, 1151 Richmond Street, London, ON, Canada. ${ }^{6}$ Health Information Research Unit, Department of Clinical Epidemiology and Biostatistics, McMaster University, 1280 Main Street West, Hamilton, ON, Canada.

\section{Authors' contributions}

$\mathrm{RBH}$ was responsible for study conception and design; acquisition, analysis, and interpretation of data; drafting and critical revision of the manuscript; obtaining funding; study supervision. He is the guarantor. PSR acquired, analyzed, and interpreted data; drafted and critically revised the manuscript; and conducted statistical analysis. SM acquired data; drafted and critically revised the manuscript. HCG analyzed and interpreted data; and critically revised the manuscript. AXG acquired, analyzed, and interpreted data; and critically revised the manuscript. RJS analyzed and interpreted the data. JAM 
acquired, analyzed, and interpreted data; and critically revised the manuscript. LWK and TN acquired data and drafted the manuscript. NLW acquired, analyzed, and interpreted data; provided administrative, technical, or material support; and provided study supervision. All authors read and approved the final manuscript.

\section{Competing interests}

RBH, PSR, SM, HCG, AXG, RJS, JAM, NMS, LWK, and TN received support through the Canadian Institutes of Health Research Synthesis Grant: Knowledge Translation KRS 91791 for the submitted work. PSR was also supported by an Ontario Graduate Scholarship, a Canadian Institutes of Health Research Strategic Training Fellowship, and a Canadian Institutes of Health Research 'Banting and Best' Master's Scholarship. Additionally, PSR is a co-applicant for a patent concerning computerized decision support for anticoagulation, which was not discussed in this review, and has recently received awards from organizations that may benefit from the notion that information technology improves health care, including $\mathrm{COACH}$ (Canadian Organization for Advancement of Computers in Healthcare), the National Institutes of Health Informatics, and Agfa HealthCare Corp. RJS is the owner of Fig.P Software Incorporated, which develops and sells a chronic disease management system that is not a subject of this review. HCG has/had financial relationships with the following organisations in the previous three years: Sanofi Aventis, GlaxoSmithKline, Eli Lilly, Novo Nordisk, Astra Zeneca, BMS, Roche, Bayer, Janssen Ortho, Solvay, BI, Servier. RBH is acquainted with several CCDSS developers and researchers, including authors of papers included in this review.

Received: 5 April 2011 Accepted: 3 August 2011

Published: 3 August 2011

\section{References}

1. Fortin M, Bravo G, Hudon C, Vanasse A, Lapointe L: Prevalence of multimorbidity among adults seen in family practice. Ann Fam Med 2005, 3(3):223-228

2. Holbrook A, Thabane L, Keshavjee K, Dolovich L, Bernstein B, Chan D, Troyan S, Foster G, Gerstein H: Individualized electronic decision support and reminders to improve diabetes care in the community: COMPETE ॥ randomized trial. CMAJ 2009, 181(1-2):37-44.

3. Holbrook A, Keshavjee K, Lee H, Bernstein B, Chan D, Thabane L, Gerstein H, Troyan S, COMPETE II Investigators: Individualized electronic decision support and reminders can improve diabetes care in the community. AMIA Annu Symp Proc 2005, 982.

4. Garg AX, Adhikari NK, McDonald H, Rosas-Arellano M, Devereaux PJ, Beyene J, Sam J, Haynes RB: Effects of computerized clinical decision support systems on practitioner performance and patient outcomes: a systematic review. JAMA 2005, 293(10):1223-1238.

5. Shojania KG, Jennings A, Mayhew A, Ramsay C, Eccles M, Grimshaw J: Effect of point-of-care computer reminders on physician behaviour: $a$ systematic review. CMAJ 2010, 182(5):E216-E225.

6. Pearson SA, Moxey A, Robertson J, Hains I, Williamson M, Reeve J, Newby D: Do computerised clinical decision support systems for prescribing change practice? A systematic review of the literature (19902007). BMC Health Serv Res 2009, 9:154

7. Durieux P, Trinquart L, Colombet I, Nies J, Walton R, Rajeswaran A, Rege Walther M, Harvey E, Burnand B: Computerized advice on drug dosage to improve prescribing practice. Cochrane Database Syst Rev 2008, , 3: CD002894.

8. Berner ES: Clinical decision support systems: State of the art. AHRQ Publication No 09-0069-EF Rockville, Maryland: Agency for Healthcare Research and Quality; 2009.

9. Haynes RB, Wilczynski NL, the Computerized Clinical Decision Support System (CCDSS) Systematic Review Team: Effects of computerized clinical decision support systems on practitioner performance and patient outcomes: methods of a decision-maker-research partnership systematic review. Implement Sci 2010, 5:12.

10. Fihn SD, McDonell MB, Vermes D, Henikoff JG, Martin DC, Callahan CM, Kent $\mathrm{DL}$, White $\mathrm{RH}$ : A computerized intervention to improve timing of outpatient follow-up: a multicenter randomized trial in patients treated with warfarin. National Consortium of Anticoagulation Clinics. J Gen Intern Med 1994, 9(3):131-139.
11. MacLean CD, Gagnon M, Callas P, Littenberg B: The Vermont Diabetes Information System: a cluster randomized trial of a population based decision support system. J Gen Intern Med 2009, 24(12):1303-1310.

12. MacLean CD, Littenberg B, Gagnon M: Diabetes decision support: initial experience with the Vermont diabetes information system. Am J Public Health 2006, 96(4):593-595.

13. Christian JG, Bessesen DH, Byers TE, Christian KK, Goldstein MG, Bock BC: Clinic-based support to help overweight patients with type 2 diabetes increase physical activity and lose weight. Arch Intern Med 2008, 168(2):141-146.

14. Cleveringa FG, Gorter KJ, van den Donk M, Rutten GE: Combined task delegation, computerized decision support, and feedback improve cardiovascular risk for type 2 diabetic patients: a cluster randomized trial in primary care. Diabetes Care 2008, 31(12):2273-2275.

15. Cleveringa FGW, Gorter KJ, van den Donk M, Pijman PLW, Rutten GEHM: Task delegation and computerized decision support reduce coronary heart disease risk factors in type 2 diabetes patients in primary care. Diabetes Technol Ther 2007, 9(5):473-481.

16. Cleveringa FG, Welsing PM, van den Donk M, Gorter KJ, Niessen LW, Rutten GE, Redekop WK: Cost-effectiveness of the diabetes care protocol, a multifaceted computerized decision support diabetes management intervention that reduces cardiovascular risk. Diabetes Care 2010, 33(2):258-263.

17. Cleveringa FGW, Minkman MH, Gorter KJ, van den Donk M, Rutten G: Diabetes Care Protocol: effects on patient-important outcomes. A cluster randomised non-inferiority trial in primary care. Diabetes Med 2010, 27(4):442-450.

18. Peterson KA, Radosevich DM, O'Connor PJ, Nyman JA, Prineas RJ, Smith SA, Arneson TJ, Corbett VA, Weinhandl JC, Lange CJ, Hannan PJ: Improving diabetes care in practice: findings from the TRANSLATE trial. Diabetes Care 2008, 31(12):2238-2243.

19. Quinn CC, Clough SS, Minor JM, Lender D, Okafor MC, Gruber-Baldini A: WellDoc $^{\mathrm{TM}}$ mobile diabetes management randomized controlled trial: change in clinical and behavioral outcomes and patient and physician satisfaction. Diabetes Technol Ther 2008, 10(3):160-168.

20. Augstein $P$, Vogt $L$, Kohnert KD, Freyse EJ, Heinke P, Salzsieder E: Outpatient assessment of Karlsburg Diabetes Management Systembased decision support. Diabetes Care 2007, 30(7):1704-1708.

21. Filippi A, Sabatini A, Badioli L, Samani F, Mazzaglia G, Catapano A, Cricelli C: Effects of an automated electronic reminder in changing the antiplatelet drug-prescribing behavior among Italian general practitioners in diabetic patients: an intervention trial. Diabetes Care 2003, 26(5):1497-1500.

22. Meigs JB, Cagliero E, Dubey A, Murphy-Sheehy P, Gildesgame C, Chueh H, Barry MJ, Singer DE, Nathan DM: A controlled trial of web-based diabetes disease management: the MGH diabetes primary care improvement project. Diabetes Care 2003, 26(3):750-757.

23. Lobach DF, Hammond W: Computerized decision support based on a clinical practice guideline improves compliance with care standards. Am J Med 1997, 102(1):89-98.

24. Nilasena DS, Lincoln MJ: A computer-generated reminder system improves physician compliance with diabetes preventive care guidelines. Proc Annu Symp Comput Appl Med Care 1995, 640-645.

25. Mazzuca SA, Vinicor F, Einterz RM, Tierney WM, Norton JA, Kalasinski LA: Effects of the clinical environment on physicians' response to postgraduate medical education. Am Educ Res J 1990, 27(3):473-488.

26. Thomas JC, Moore A, Qualls PE: The effect on cost of medical care for patients treated with an automated clinical audit system. J Med Syst 1983, 7(3):307-313.

27. Derose SF, Dudl JR, Benson VM, Contreras R, Nakahiro RK, Ziel FH: Point of service reminders for prescribing cardiovascular medications. Am J Manag Care 2005, 11(5):298-304.

28. Sequist TD, Gandhi TK, Karson AS, Fiskio JM, Bugbee D, Sperling M, Cook EF, Orav EJ, Fairchild DG, Bates DW: A randomized trial of electronic clinical reminders to improve quality of care for diabetes and coronary artery disease. J Am Med Inform Assoc 2005, 12(4):431-437.

29. Martin DC, Berger ML, Anstatt DT, Wofford J, Warfel D, Turpin RS, Cannuscio CC, Teutsch SM, Mansheim BJ: A randomized controlled open trial of population-based disease and case management in a Medicare Plus Choice health maintenance organization. Prev Chronic Dis 2004, 1(4): A05. 
30. Demakis JG, Beauchamp C, Cull WL, Denwood R, Eisen SA, Lofgren R, Nichol K, Woolliscroft J, Henderson WG: Improving residents' compliance with standards of ambulatory care: results from the VA Cooperative Study on Computerized Reminders. JAMA 2000, 284(11):1411-1416.

31. Hetlevik I, Holmen J, Krüger O: Implementing clinical guidelines in the treatment of hypertension in general practice. Evaluation of patient outcome related to implementation of a computer-based clinical decision support system. Scand J Prim Health Care 1999, 17(1):35-40.

32. Hetlevik I, Holmen J, Kruger O, Kristensen P, Iversen H: Implementing clinical guidelines in the treatment of hypertension in general practice. Blood Press 1998, 7(5-6):270-276.

33. Hetlevik I, Holmen J, Krüger $O$, Kristensen $P$, Iversen $H$, Furuseth $K$ : Implementing clinical guidelines in the treatment of diabetes mellitus in general practice. Evaluation of effort, process, and patient outcome related to implementation of a computer-based decision support system. Int J Technol Assess 2000, 16(1):210-227.

34. Bosworth HB, Olsen MK, Dudley T, Orr M, Goldstein MK, Datta SK, McCant F, Gentry P, Simel DL, Oddone EZ: Patient education and provider decision support to control blood pressure in primary care: a cluster randomized trial. Am Heart J 2009, 157(3):450-456.

35. Hicks LS, Sequist TD, Ayanian JZ, Shaykevich S, Fairchild DG, Orav EJ Bates DW: Impact of computerized decision support on blood pressure management and control: a randomized controlled trial. J Gen Intern Med 2008, 23(4):429-441.

36. Borbolla D, Giunta D, Figar S, Soriano M, Dawidowski A, de Quiros FG: Effectiveness of a chronic disease surveillance systems for blood pressure monitoring. Stud Health Technol Inform 2007, 129(Pt 1):223-227.

37. Mitchell E, Sullivan F, Watt G, Grimshaw JM, Donnan PT: Using electronic patient records to inform strategic decision making in primary care. Stud Health Technol Inform 2004, 107(Pt2):1157-1161.

38. Murray MD, Harris LE, Overhage JM, Zhou XH, Eckert GJ, Smith FE, Buchanan NN, Wolinsky FD, McDonald CJ, Tierney WM: Failure of computerized treatment suggestions to improve health outcomes of outpatients with uncomplicated hypertension: results of a randomized controlled trial. Pharmacotherapy 2004, 24(3):324-337.

39. Montgomery AA, Fahey T, Peters TJ, Maclntosh C, Sharp DJ: Evaluation of computer based clinical decision support system and risk chart for management of hypertension in primary care: randomised controlled trial. BMJ 2000, 320(7236):686-690.

40. Rossi RA, Every NR: A computerized intervention to decrease the use of calcium channel blockers in hypertension. J Gen Intern Med 1997, 12(11):672-678.

41. McAlister NH, Covvey HD, Tong C, Lee A, Wigle ED: Randomised controlled trial of computer assisted management of hypertension in primary care. Br Med J (Clin Res Ed) 1986, 293(6548):670-674.

42. Rogers $J$, Haring OM, Goetz JP: Changes in patient attitudes following the implementation of a medical information system. QRB Qual Rev Bull 1984, 10(3):65-74.

43. Rogers JL, Haring OM, Wortman PM, Watson RA, Goetz JP: Medical information systems: assessing impact in the areas of hypertension, obesity and renal disease. Med Care 1982, 20(1):63-74.

44. Rogers $J$, Haring OM: The impact of a computerized medical record summary system on incidence and length of hospitalization. Med Care 1979, 17(6):618-630.

45. Coe FL, Norton E, Oparil S, Tatar A, Pullman TN: Treatment of hypertension by computer and physician-a prospective controlled study. J Chronic Dis 1977, 30(2):81-92.

46. Fiks AG, Hunter KF, Localio AR, Grundmeier RW, Bryant-Stephens T, Luberti AA, Bell LM, Alessandrini EA: Impact of electronic health recordbased alerts on influenza vaccination for children with asthma. Pediatrics 2009, 124(1):159-169.

47. Poels PJ, Schermer TR, Thoonen BP, Jacobs JE, Akkermans RP, de Vries Robbe PF, Quanjer PH, Bottema BJ, van Weel C: Spirometry expert support in family practice: a cluster-randomised trial. Prim Care Respir J 2009, 18(3):189-197.

48. Martens JD, van der Weijden $T$, Severens $J$, de Clercq PA, de Bruijn DP, Kester AD, Winkens RA: The effect of computer reminders on $\mathrm{GPs}^{\prime}$ prescribing behaviour: a cluster-randomised trial. Int J Med Inform 2007, 76(Suppl 3):S403-S416

49. Martens JD, van der Aa A, Panis B, van der Weijden T, Winkens RA, Severens $\mathrm{J}$ : Design and evaluation of a computer reminder system to improve prescribing behaviour of GPs. Stud Health Technol Inform 2006, 124:617-623.

50. Kattan M, Crain EF, Steinbach S, Visness CM, Walter M, Stout JW, Evans lii R, Smartt E, Gruchalla RS, Morgan WJ: A randomized clinical trial of clinician feedback to improve quality of care for inner-city children with asthma. Pediatrics 2006, 117(6):e1095-e1103.

51. Kuilboer MM, van Wijk MA, Mosseveld M, van der Does E, de Jongste JC, Overbeek SE, Ponsioen B, van der Lei J: Computed critiquing integrated into daily clinical practice affects physicians' behavior-a randomized clinical trial with AsthmaCritic. Methods Inf Med 2006, 45(4):447-454.

52. Plaza V, Cobos A, Ignacio-Garcia JM, Molina J, Bergonon S, Garcia-Alonso F, Espinosa C, Grupo Investigador A: [Cost-effectiveness of an intervention based on the Global INitiative for Asthma (GINA) recommendations using a computerized clinical decision support system: a physicians randomized trial]. Med Clin (Barc) 2005, 124(6):201-206.

53. Tierney WM, Overhage JM, Murray MD, Harris LE, Zhou XH, Eckert GJ, Smith FE, Nienaber N, McDonald CJ, Wolinsky FD: Can computergenerated evidence-based care suggestions enhance evidence-based management of asthma and chronic obstructive pulmonary disease? A randomized, controlled trial. Health Serv Res 2005, 40(2):477-497.

54. Eccles M, McColl E, Steen N, Rousseau N, Grimshaw J, Parkin D, Purves I: Effect of computerised evidence based guidelines on management of asthma and angina in adults in primary care: cluster randomised controlled trial. BMJ 2002, 325(7370):941.

55. Rousseau N, McColl E, Newton J, Grimshaw J, Eccles M: Practice based, longitudinal, qualitative interview study of computerised evidence based guidelines in primary care. BMJ 2003, 326(7384):314.

56. McCowan C, Neville RG, Ricketts IW, Warner FC, Hoskins G, Thomas GE: Lessons from a randomized controlled trial designed to evaluate computer decision support software to improve the management of asthma. Med Inform Internet 2001, 26(3):191-201.

57. Bertoni AG, Bonds DE, Chen H, Hogan P, Crago L, Rosenberger $E$, Barham AH, Clinch CR, Goff DC Jr: Impact of a multifaceted intervention on cholesterol management in primary care practices: guideline adherence for heart health randomized trial. Arch Intern Med 2009, 169(7):678-686.

58. Rosenberger EL, Goff DC Jr, Blackwell CS, Williams DT, Crago OL, Ellis SD, Bertoni AG, Bonds DE: Implementing a palm pilot intervention for primary care providers: lessons learned. Contemp Clin Trials 2009, 30(4):321-325.

59. Gilutz H, Novack L, Shvartzman P, Zelingher J, Bonneh DY, Henkin Y, Maislos M, Peleg R, Liss Z, Rabinowitz G, Vardy D, Zahger D, Ilia R, Leibermann N, Porath A: Computerized community cholesterol control (4C): meeting the challenge of secondary prevention. Israel Med Assoc J 2009, 11(1):23-29.

60. Lester WT, Grant RW, Barnett GO, Chueh HC: Randomized controlled trial of an informatics-based intervention to increase statin prescription for secondary prevention of coronary disease. J Gen Intern Med 2006, 21(1):22-29.

61. Lester WT, Grant R, Barnett GO, Chueh H: Facilitated lipid management using interactive e-mail: preliminary results of a randomized controlled trial. Stud Health Technol Inform 2004, 107(Pt 1):232-236.

62. Cobos A, Vilaseca J, Asenjo C, Pedro-Botet J, Sanchez E, Val A, Torremade E, Espinosa C, Bergonon S: Cost effectiveness of a clinical decision support system based on the recommendations of the European Society of Cardiology and other societies for the management of hypercholesterolemia: Report of a cluster-randomized trial. Dis Manag Health Out 2005, 13(6):421-432.

63. Goud R, de Keizer NF, ter Riet G, Wyatt JC, Hasman A, Hellemans IM, Peek N: Effect of guideline based computerised decision support on decision making of multidisciplinary teams: cluster randomised trial in cardiac rehabilitation. BMJ 2009, 338:b1440.

64. Goud R, Jaspers MW, Hasman A, Peek N: Subjective usability of the CARDSS guideline-based decision support system. Stud Health Technol Inform 2008, 138:193-198.

65. Feldman PH, Murtaugh CM, Pezzin LE, McDonald MV, Peng TR: Just-in-time evidence-based e-mail 'reminders' in home health care: impact on patient outcomes. Health Serv Res 2005, 40(3):865-885.

66. Murtaugh CM, Pezzin LE, McDonald MV, Feldman PH, Peng TR: Just-in-time evidence-based e-mail 'reminders' in home health care: impact on nurse practices. Health Serv Res 2005, 40(3):849-864. 
67. Tierney WM, Overhage JM, Murray MD, Harris LE, Zhou XH, Eckert GJ, Smith FE, Nienaber N, McDonald CJ, Wolinsky FD: Effects of computerized guidelines for managing heart disease in primary care. $J$ Gen Intern Med 2003, 18(12):967-976.

68. Lee NJ, Chen ES, Currie LM, Donovan M, Hall EK, Jia H, John RM, Bakken S: The effect of a mobile clinical decision support system on the diagnosis of obesity and overweight in acute and primary care encounters. ANS Adv Nurs Sci 2009, 32(3):211-221.

69. Bakken S, Cook SS, Curtis L, Desjardins K, Hyun S, Jenkins M, John R, Klein WT, Paguntalan J, Roberts WD, Soupios M: Promoting patient safety through informatics-based nursing education. Int J Med Inform 2004, 73(7-8):581-589.

70. Locatelli F, Covic A, Macdougall IC, Scherhag A, Wiecek A, ORAMA Study Group: Effect of computer-assisted European Best Practice Guideline implementation on adherence and target attainment: ORAMA results. $J$ Nephrol 2009, 22(5):662-674.

71. Javitt JC, Rebitzer JB, Reisman L: Information technology and medical missteps: evidence from a randomized trial. J Health Econ 2008, 27(3):585-602.

72. Verstappen SMM, Jacobs JWG, Van der Veen MJ, Heurkens AHM, Schenk Y, Ter Borg EJ, Blaauw AAM, Bij|sma JWJ: Intensive treatment with methotrexate in early rheumatoid arthritis: aiming for remission. Computer Assisted Management in Early Rheumatoid Arthritis (CAMERA, an open-label strategy trial). Ann Rheum Dis 2007, 66(11):1443-1449.

73. Downs M, Turner S, Bryans M, Wilcock J, Keady J, Levin E, O'Carroll R, Howie $K$, lliffe $S$ : Effectiveness of educational interventions in improving detection and management of dementia in primary care: cluster randomised controlled study. BMJ 2006, 332(7543):692-696.

74. Feldstein A, Elmer PJ, Smith DH, Herson M, Orwoll E, Chen C, Aickin M, Swain MC: Electronic medical record reminder improves osteoporosis management after a fracture: a randomized, controlled trial. J Am Geriatr Soc 2006, 54(3):450-457.

75. McDonald MV, Pezzin LE, Feldman PH, Murtaugh CM, Peng TR: Can just-intime, evidence-based 'reminders' improve pain management among home health care nurses and their patients? I Pain Symptom Manage 2005, 29(5):474-488.

76. Dexter PR, Wolinsky FD, Gramelspacher GP, Zhou XH, Eckert GJ, Waisburd M, Tierney WM: Effectiveness of computer-generated reminders for increasing discussions about advance directives and completion of advance directive forms. A randomized, controlled trial. Ann Intern Med 1998, 128(2):102-110

77. Rubenstein LV, McCoy JM, Cope DW, Barrett PA, Hirsch SH, Messer KS, Young RT: Improving patient quality of life with feedback to physicians about functional status. J Gen Intern Med 1995, 10(11):607-614.

78. Petrucci K, Petrucci P, Canfield K, McCormick KA, Kjerulff K, Parks P: Evaluation of UNIS: Urological Nursing Information Systems. Proc Annu Symp Comput Appl Med Care 1991, 43-47.

79. McDonald CJ, Hui SL, Smith DM, Tierney WM, Cohen SJ, Weinberger M, McCabe GP: Reminders to physicians from an introspective computer medical record. A two-year randomized trial. Ann Intern Med 1984, 100(1):130-138.

80. Sackett DL, Snow JC: The magnitude of adherence and non-adherence. In Adherence in Health Care. Edited by: Haynes RB, Taylor DW, Sackett DL. Baltimore: Johns Hopkins University Press; 1979:

81. Wright A, Sittig DF, Ash JS, Sharma S, Pang JE, Middleton B: Clinical decision support capabilities of commercially-available clinical information systems. J Am Med Inform Assoc 2009, 16(5):637-644.

82. Hedges LV, Olkin I: Statistical methods for meta-analysis Orlando: Academic Press; 1985.

83. Kawamoto K, Houlihan CA, Balas EA, Lobach DF: Improving clinical practice using clinical decision support systems: a systematic review of trials to identify features critical to success. BMJ 2005, 330(7494):765.

84. Jaspers MW, Smeulers M, Vermeulen H, Peute LW: Effects of clinical decision-support systems on practitioner performance and patient outcomes: a synthesis of high-quality systematic review findings. J Am Med Inform Assoc 2011, 18(3):327-334.

doi:10.1186/1748-5908-6-92

Cite this article as: Roshanov et al: Computerized clinical decision support systems for chronic disease management: A decision-makerresearcher partnership systematic review. Implementation Science 2011 6:92.

\section{Submit your next manuscript to BioMed Central and take full advantage of:}

- Convenient online submission

- Thorough peer review

- No space constraints or color figure charges

- Immediate publication on acceptance

- Inclusion in PubMed, CAS, Scopus and Google Scholar

- Research which is freely available for redistribution

Submit your manuscript at www.biomedcentral.com/submit
C Biomed Central 